Agronomy

\title{
Seedling traits of maize as indicators of root lodging
}

\author{
P Stamp, C Kiel \\ Swiss Federal Institute of Technology, Institute of Plant Sciences, Universität-strasse 2, 8092 Zürich, Switzerland
}

(Received 22 May 1991; accepted 25 November 1991)

\begin{abstract}
Summary - Research was undertaken to determine whether root lodging of maize (Zea mays $L$ ) can be predicted at the seedling stage. In the first experiment, seedlings from 9 central European flint $x$ dent hybrids were tested under controlled conditions. At the 3-leaf stage, the diameter of the primary root was closely and negatively correlated with root lodging counts from field trials when plants were grown at $14{ }^{\circ} \mathrm{C}$, but not at $22{ }^{\circ} \mathrm{C}$. Attempts to test at an earlier seedling stage were only successful at $22^{\circ} \mathrm{C}$ and after 4 days of germination in the dark; the number of late/large metaxylem vessels in the primary root was closely and negatively correlated with root lodging. Experiment 2, with 14 hybrids tested for root lodging at one location for 2 years, partly confirmed the results of the first experiment. In experiment 3 , root lodging data at anthesis and maturity were available from subsets of 10 to 17 hybrids from a total of 28 hybrids at 14 locations in Germany over 3 years. Root lodging at anthesis and at harvest were significantly negatively correlated with: a), the number of large metaxylem vessels in 21 out of 84 cases (range of significance $r=-0.51$ to -0.70 ); and $b$ ), with coleoptile length in 15 cases (range of significance $r=-0.51$ to - 0.79. We conclude that, in principle, a very early detection of root lodging resistance is possible. The same genetic systems seem to contribute to relevant root and shoot traits in seedlings and adult plants.
\end{abstract}

maize / root lodging / root histology

Résumé - Caractéristiques des plantules comme indicateurs de verse racinaire. Des recherches ont été entreprises pour déterminer si la verse racinaire du Maïs (Zea mays L) peut être prédite au stade de plantule. Des plantules de 9 hybrides (corné $\times$ denté) d'Europe centrale ont été testées en conditions contrôlées dans une première expérience. Au stade 3 feuilles, le diamètre de la racine primaire était fortement et négativement correlé avec la verse racinaire au champ chez les plantes qui avaient poussé à $14^{\circ} \mathrm{C}$, mais pas chez celles qui avaient poussé à $22{ }^{\circ} \mathrm{C}$. Des tentatives pour tester les plantules à un stade très précoce n'ont été concluantes qu'à $22^{\circ} \mathrm{C}$. Après $4 j$ de germination à l'obscurité, le nombre de vaisseaux tardifs/gros du métaxylème dans la racine primaire était fortement et négativement corrélé avec la verse racinaire. Une deuxième et une troisième expérience ont été réalisées exclusivement pour des stades précoces des plantules avec d'autres lots d'hybrides (corné $\times$ denté). La deuxième expérience, dans laquelle la verse racinaire de 14 hybrides a été testée pour 1 lieu et 2 années, a permis de confirmer partiellement les résultats obtenus lors de la première expérience. Pour la troisième expérience, des données relatives à la verse racinaire à l'anthèse et à la maturité issues de 14 lieux et de 3 années étaient disponibles pour 10-17 sous-lots d'un total de 28 hybrides. La verse racinaire à l'anthèse et à la récolte était correlée d'une manière négative et significative

- avec le nombre de gros vaisseaux du métaxylème pour 21 des 84 cas $(r=0,51-0,70)$ et

- avec la longueur du coléoptile dans 15 cas $(r=-0,51-0,79)$. Nous avons alors conclu qu'en principe, une détection très précoce de la résistance à la verse racinaire était possible. Apparemment, les mêmes systèmes génotypiques contribuent aux caractères déterminants de la racine et de la tige des plantules et des plantes adultes.

maïs / verse racinaire / histologie des racines 


\section{INTRODUCTION}

Root lodging can reduce the quantity and quality of maize yield in many growing regions. In the USA, genetic yield gains have been accompanied by large and consistent improvements in root lodging resistance during the last 50 years (Duvick, 1984). According to Russel (1984), highly significant gains for root lodging resistance were observed during the 1930s, while subsequent additional gains were insignificant.

Selection for resistance is normally carried out where root lodging is a problem. Root lodging occurs very irregularly because it is greatly influenced by soil fertility, wind and other environmental factors. For these reasons, consistent progress in selection is difficult to maintain even in small trials. According to several authors, root pulling resistance around anthesis is less dependent on environment than root lodging itself (Rogers et al, 1976; Peters et al, 1982; Kevern and Hallauer, 1983). In the USA, correlation with observed root lodging and heritability of root pulling resistance has seemed to be sufficient for selection, contrary to investigations in Japan and central Europe (Melchinger et al, 1986; Yamada and Ishige, 1988).

Attempts have been made to shift testing to an earlier date since an improvement by the indirect method of root pulling does not seem feasible (Arihara and Crosbie, 1982; Fincher et al, 1985). The results were not in favour of a much earlier date than anthesis itself. However, significant negative correlations seem to exist between the percentage of seminal roots of seedlings and the root pulling resistance of mature plants (Andrew and Solanski, 1966; Nass and Zuber, 1971).

At an early seedling stage, the amount of genotypic variability in root morphology is already large (Stamp, 1984). The question arises as to whether the responsible genetic systems are still active at later growth stages. The objective of the present study was to investigate relationships of early seedling traits with root lodging. Early maturing central European hybrids were chosen for these studies. They had been selected previously for a good lodging resistance. A multitude of root lodging data from field tests were used for correlation studies with seedling traits. The high number of field sites and years compensates, to some extent, for the irregular occurrence of root lodging.

\section{MATERIALS AND METHODS}

The first seedling experiment was conducted with 9 early maturing flint $x$ dent test and commercial hybrids $(2958 \times 2807,2958 \times Z 35,2863 \times Z$ 80010, Z $79510 \times Z 77020$, Z $79521 \times Z 80060$, $Z 80552 \times 2804$ and 171781 from Saatenunion, Bastion, Forla) which had been grown previously at 4 field locations in 1983: The Netherlands; and southern, central and northern Germany. In order to verify the results of experiment 1 , a second experiment was carried out with 16 early maturing flint $\times$ dent hybrid seedlings (Hit, Bastion, Balda, Felix, Samson, Tan, Ass, KX 843 A, Forla, Protagold, Primeur, Keo, Eta, Blizzard, KX 716 $T$, Leader). Root lodging counts for these hybrids had been made at an experimental field near Kiel, northern Germany, in 1982 and 1983. For further confirmation of the results, a third seedling experiment was performed with 28 commercial flint $\times$ dent hybrids (Alize, Regent, Samson, Ass, Bastion, Forla, Tau, Balda, Blizzard, Brillant, Felix, Leader, Santos, Brummi, Garant, Golda, Mutin, Sava, Anko, Limac, Passat, Pinto, Protador, Circe, Suroit, Dorina, Baroness, Frontenac; for a detailed description see "Beschreibende Sortenliste", Germany). These had been tested in subsets of 10-17 hybrids in variety tests at 14 locations from 1982-1984. These field trials were conducted by the agricultural extension services of Lower Saxony and Bavaria.

Root lodging counts from a total of 48 field trials were available for comparison with data from the 3 seedling experiments. In all field trials, plant densities ranged from 10-12 per $\mathrm{m}^{2}$. Seeds were sown at the end of April or the beginning of May. Herbicides and fertilizers were applied according to the regional recommendations. The soil textures were sandy loam or loam. Randomized block designs with 4 replications were used, and each plot had 3 rows. The percentage of root lodged plants was calculated from the center rows at harvest in October. All stems which deviated by more than $45^{\circ}$ from the vertical were considered to be lodged. In the third set of 42 field trials from 1982-1984, root lodging was additionally estimated at anthesis, using scores ranging from $1=$ no lodging to $9=$ all plants lodged.

In the first experiment, seedlings from the 9 hybrids were grown in polyethylene tubes (diameter $6 \mathrm{~cm}$, length $45 \mathrm{~cm}$ ) at $22^{\circ} \mathrm{C}$ or at $14^{\circ} \mathrm{C}$ in a Conviron growth chamber until the 3-leaf stage (2 or 5 weeks). Twelve replications were used in a randomized block design. The tubes were filled with loamy sand ( $80 \%$ sand) which contained $12 \%$ weight of an $\mathrm{N}$-free Hoagland solution. The light intensity was $50 \mathrm{~W} \mathrm{~m}^{-2}$ at shoot height. Roots were washed and length and diameter of primary and mesocotyl roots were measured; the number, length and diameter of the lateral roots from pri- 
mary and mesocotyl roots were noted (see Stamp, 1984 for details).

Seedling studies were carried out with hybrids from all 3 experiments at a very early seedling stage. For this purpose, kernels were washed and soaked in water at $18^{\circ} \mathrm{C}$ for $12 \mathrm{~h}$. They were then placed in trays on wet foam rubber at $22^{\circ} \mathrm{C}$. For root and coleoptile studies, the trays were covered by black polyethylene sheets to exclude light. For additional coleoptile studies in experiment 3, transparent polyethylene sheets were used with a light intensity of $50 \mathrm{~W} \mathrm{~m}^{-2}$. Twenty seedlings from each hybrid, distributed in 4 blocks, were harvested after 4 days of germination. The length of the coleoptile (from node to tip) and primary root (from kernel to tip) were measured at once and mesocotyl roots were counted. Primary roots of seedlings grown in the dark were then cut at the base and stored in a glutardialdehyde (5\%) solution. Cross-sections of these roots were studied every $4 \mathrm{~cm}$ from the base, and the diameters of the root, stele, and early (small) and late (large) metaxylem vessels were measured with the aid of a microscope. The numbers of small and large metaxylem vessels were counted.

Mean values for each hybrid and for each trait were used to calculate phenotypic correlations and multiple linear regressions between seedling traits from growth chambers and root lodging data from field trials.

\section{RESULTS AND DISCUSSION}

\section{Experiment 1}

Experiment 1 was based on observations that maize genotypes could be differentiated by distinct patterns of root development already at the 3-leaf stage and that significant interactions between cultivars and growth temperatures exist (Stamp, 1984). Of the seedling traits examined (length and diameter of main roots and number, length and diameter of lateral roots), only the diameter at the mid-point of approximately $40 \mathrm{~cm}$ long primary roots correlated significantly and negatively with the percentage of root lodging in 4 environments (table 1). The strongest correlations were found for seedlings grown at $14^{\circ} \mathrm{C}$. Such investigations are laborious and time-consuming, 5 weeks being needed to reach the 3-leaf stage at $14^{\circ} \mathrm{C}$.

Since root diameter varied greatly, the root anatomy of plants in Experiment 1 was subsequently studied. Xylem traits (number of small and large metaxylem vessels and their respective diameters) were closely and negatively correlated with root lodging even when seedlings were grown at $22^{\circ} \mathrm{C}$ instead of $14{ }^{\circ} \mathrm{C}$ for 4 days only (table I)!

\section{Experiment 2}

In a second experiment with 16 hybrids, it was confirmed that xylem-related traits of the primary root, such as the number of large metaxylem vessels, were closely correlated with root lodging which was not the case with the diameter of 4-day old seedlings (table II).

Table I. Correlation of root lodging with the diameter of primary roots at the 3-leaf stage after growth at $22{ }^{\circ} \mathrm{C}$ and $14{ }^{\circ} \mathrm{C}$, and with the number of large metaxylem vessels of the primary root from 4-day-old seedlings germinated at $22^{\circ} \mathrm{C}$. Root lodging data are derived from 9 test hybrids in 4 environments (Experiment 1).

\begin{tabular}{lccccc}
\hline \multicolumn{1}{c}{ Trait } & $\begin{array}{c}\text { Growth } \\
\text { temperature } \\
\text { (seedlings) } \\
\left({ }^{\circ} \mathrm{C}\right)\end{array}$ & $\begin{array}{c}\text { Waterneversdorf } \\
\text { (northern } \\
\text { Germany) }\end{array}$ & $\begin{array}{c}\text { Söllingen } \\
\text { (central } \\
\text { Germany) }\end{array}$ & $\begin{array}{c}\text { Mannheim } \\
\text { (Southern } \\
\text { Germany) }\end{array}$ & $\begin{array}{c}\text { No-Polder } \\
\text { (Netherlands) }\end{array}$ \\
\hline $\begin{array}{lcccc}\text { Diameter } \\
\text { of primary root }\end{array}$ & 22 & -0.58 & -0.65 & $-0.71^{*}$ & -0.62 \\
$\begin{array}{l}\text { No of large } \\
\text { metaxylem vessels }\end{array}$ & 14 & $-0.94^{*}$ & $-0.80^{*}$ & $-0.89^{*}$ & $-0.67^{*}$ \\
of primary root & 22 & $-0.86^{*}$ & $-0.90^{*}$ & $-0.90^{*}$ & $-0.79^{*}$ \\
\hline
\end{tabular}

* Significant at $P=0.05$. 
Table II. Correlation of root lodging of 14 hybrids with primary root traits of 4- day-old seedlings (field trial at the University of Kiel) (Experiment 2).

\begin{tabular}{lcc}
\hline \multicolumn{1}{c}{ Trait } & 1982 & 1983 \\
\hline Root diameter & -0.15 & -0.19 \\
$\begin{array}{l}\text { No of large } \\
\text { metaxylem vessels }\end{array}$ & 0.48 & $-0.79^{*}$ \\
\hline
\end{tabular}

* Significant at $P=0.05$

\section{Experiment 3}

Root lodging is a trait which is difficult to reproduce because minor variations in soil conditions and wind velocity can have a strong effect (cf Melchinger et al, 1986). For this reason, seedling studies were continued with 28 commercial hybrids in Experiment 3 in order to utilize root lodging data from numerous official variety trials which are being carried out in various parts of Germany.

Examples from field trials in the northern and southern parts of Germany are presented if at least one seedling trait correlated significantly with root lodging (table III). It was characteristic that correlations for root lodging were rarely the same at anthesis and at harvest within the same trial. Contrary to the USA (Pen- ny, 1981), this is probably not due to damage to roots by insects and root rot which have been of little importance in central and western Europe up to now. Further investigations should therefore focus on the effects of climate and soil on the root system. According to Mengel and Barber (1974) and Thompson (1968), root dry weight should be at a maximum soon after anthesis. The last nodal roots elongate into the soil at or around anthesis (Picard et al, 1985). Explanations for the above-mentioned changes in correlation between anthesis and maturity may be found in the spread of roots into the soil, changes in root elasticity or in the gravity center of the shoot due to ear development.

Considering root lodging ratings at anthesis and maturity at 14 locations over 3 years, 84 analyses of correlation could be calculated for each seedling trait in Experiment 3. At the 0.05 probability level, the number of large metaxylem vessels correlated most often with 21 significant cases in the range of $r=-0.51$ to -0.79 (see table III for examples). These significant correlations for root lodging were found as often at anthesis as at maturity. Almost exclusively for root lodging at anthesis, significant correlations at the 0.05 probability level were calculated in the range of $r=-0.50$ to -0.90 for 11 cases with the coleoptile length of seedlings which had been grown in the light. Significant correlations at

Table III. Examples of correlations between root lodged plants from northern and southern Germany with seedling traits (Experiment 3).

\begin{tabular}{|c|c|c|c|c|c|c|c|}
\hline \multirow[t]{2}{*}{ Location } & \multirow[t]{2}{*}{ Year } & \multirow[t]{2}{*}{$n$} & \multirow{2}{*}{$\begin{array}{c}\text { Stage of } \\
\text { plant } \\
\text { development }\end{array}$} & \multirow[t]{2}{*}{$\begin{array}{l}\text { Range of } \\
\text { lodging }\end{array}$} & \multirow{2}{*}{$\begin{array}{c}\text { No of large } \\
\text { metaxylem } \\
\text { vessels }\end{array}$} & \multicolumn{2}{|c|}{$\begin{array}{l}\text { Length of } \\
\text { coleoptile }\end{array}$} \\
\hline & & & & & & Light & Dark \\
\hline \multicolumn{8}{|l|}{1 Lower Saxony } \\
\hline \multirow[t]{2}{*}{ Lühne } & 1984 & 15 & $A$ & $1.7-4.3^{a}$ & $-0.51^{*}$ & $-0.73^{*}$ & -0.43 \\
\hline & & 15 & $M$ & $7.0-77.0^{b}$ & -0.26 & $-0.54^{*}$ & -0.30 \\
\hline \multirow[t]{2}{*}{ Langenhaltensen } & & 18 & $A$ & $1.3-5.5^{\mathrm{a}}$ & -0.26 & $-0.50^{\circ}$ & -0.62 \\
\hline & 1984 & 18 & M & $4.0-62.0^{b}$ & -0.36 & $-0.55^{*}$ & -0.79 \\
\hline \multicolumn{8}{|l|}{2 Bavaria } \\
\hline \multirow{3}{*}{$\begin{array}{l}\text { Average of multi- } \\
\text { locational silage trials }\end{array}$} & & & & & & & \\
\hline & 1982 & 13 & $A$ & $1.1-3.9^{\mathrm{a}}$ & $-0.57^{*}$ & $-0.67^{*}$ & -0.72 \\
\hline & 1984 & 13 & M & $8.1-27.5^{b}$ & -0.45 & -0.35 & -0.73 \\
\hline \multirow{2}{*}{$\begin{array}{l}\text { Average of multi- } \\
\text { locational grain trials }\end{array}$} & 1982 & & A & $13-43^{a}$ & $-0.73^{*}$ & & \\
\hline & 1984 & 14 & $M$ & $9.5-42.6^{b}$ & $-0.59^{*}$ & $\begin{array}{l}-0.24 \\
-0.24\end{array}$ & $\begin{array}{r}-0.20 \\
-0.33\end{array}$ \\
\hline
\end{tabular}

Abbreviations: $\mathrm{A}=$ Anthesis; $\mathrm{M}=$ maturity; $\mathrm{n}=$ no of cultivars; $\mathrm{a}=$ classification from 1 ( $\mathrm{no}$ lodging) to 9 (complete lodging); $b=$ percentage of lodged plants; ${ }^{\star}$ significant at $P=0.05$. 
the 0.05 probability level between the coleoptile length of dark grown seedlings occurred almost exclusively with root lodging at maturity, in the range of $r=-0.51$ to -0.79 in 15 cases. Seedlings were grown in the light to eliminate effects of etiolation. No explanation can be offered at the moment as to why light situation seemingly influenced the nature of correlation. Remarkably, significant correlations between coleoptile length and root lodging were obtained for those analyses which showed no significant correlations between root lodging and number of large metaxylem vessels. Arndt (1974) found more vigourous plants when he selected for higher numbers of late metaxylem vessels in 7-day old seedlings. However, in Experiment 3, a correlation existed for the 28 hybrids between xylem traits and the length of the coleoptile and biomass or grain yield. Beck et al (1988) found a high negative correlation between root pulling resistance and grain yield but they used plant material which had been selected for high stalk or root strength. Composition of hybrid subgroups and severity of lodging at an experimental site had no recognizable influence on the correlations. This might be due in part to the previously discussed erratic nature of root lodging under field conditions.

\section{CONCLUSIONS}

Xylem-related seedling root traits and the length of coleoptiles seem to represent independent genetic systems which may be involved in plant development, at least up to anthesis. A large number of metaxylem vessels and long coleoptiles may be indicative of root lodging resistance in central European flint $\times$ dent material.

\section{ACKNOWLEDGMENTS}

We would like to express our gratitude for permission to use field data from variety tests which were carried out by the Bayerische Landesanstalt für Bodenkultur und Pflanzenbau; the Landwirtschaftskammer Hannover; the Landwirtschaftskammer Weser-Ems and the Landwirtschaftskammer Schleswig-Holstein.

\section{REFERENCES}

Andrew RH, Solanski SS (1966) Comparative root morphology for inbred lines of corn as related to performance. Agron $J$ 58, 415-418

Arihara J, Crosbie RM (1982) Relationships among seedling and mature root system traits of maize. Crop Sci 22, 1197-1202

Arndt H, (1974) Möglichkeiten zur Selektion bei Maisinzuchtlinien nach der Anzahl der Tracheen in der Primärwurzel von Keimpflanzen. Tagungsbericht der Akad Landwirtschaftswissenschaften DDR 127, 43-48

Beck DL, Darrah LL, Zuber MS (1988) Effect of sink level on root and stalk quality in maize. Crop Sci 28, 11-18

Duvick DN (1984) Genetic contributions to yield gains of US hybrid maize, 1930 to 1980 . In: Genetic Contributions to Yield Gains of Five Major Crop Plants. CSSA Spec Publ No 7 (Fehr, WR, ed) Am Soc Agron \& Crop Sci Soc Am, Madison, $15-47$

Fincher RR, Darrah LL, Zuber MS (1985) Root development in maize as measured by vertical pulling resistance. Maydica 30, 383-394

Kevern TC, Hallauer AR (1983) Relation of vertical root-pull resistance and flowering in maize. Crop Sci 23, 357-363

Melchinger AE, Geiger HH, Schmidt GG (1986) Vertical root-pull resistance and its relationship to root lodging and forage traits in early maturing European inbred lines and $\mathrm{F} 1$ hybrids of maize. Maydica 31, 335-348

Mengel DB, Barber SA, (1974) Development and distribution of the corn root system under field conditions. Agron J 66, 341-344

Nass HG, Zuber MS (1971) Correlation of corn (Zea mays L) roots early in development to mature root development. Crop Sci 11, 655-658

Penny LH, (1981) Vertical-pull resistance of maize inbreds and their test-crosses. Crop Sci 21, $237-240$

Peters DW, Shank DB, Nyquist WE (1982) Rootpulling resistance and its relationship to grain yield in F1 hybrids of maize. Crop Sci 22, 1112 1114

Picard D, Jordan MO, Trendel R (1985) Rythme d'apparition des racines primaires du maïs (Zea mays $\mathrm{L}$ ). I. Étude détaillée pour une variété en un lieu donné. Agronomie 5, 667-676

Rogers RR, Russel WA, Owens JC (1976) Evaluation of a vertical-pull technique in population improvement for corn rootworm tolerance. Crop Sci $16,591-594$ 
Russel WA (1984) Agronomic performance of maize cultivars representing different ears of breeding. Maydica 29, 375-390

Stamp P (1984) Chilling tolerance of young plants demonstrated on the example of maize (Zea mays L). In: Advances in Agronomy and Crop Science No 7 (Geisler G, ed) Paul Parey, Berlin
Thompson DC (1968) Field evaluation of corn root clumps. Argon J 60, 170-172

Yamada M, Ishige $T$ (1988) Genetical analysis of resistance to root-lodging in maize based upon discriminant function of biometrical traits. Jpn Agric Rex $Q$ 22, 1-6 